\title{
Water Supply Reliability of Agricultural Reservoirs under Varying Climate and Rice Farming Practices
}

\author{
Gun-Ho Cho ${ }^{1}$, Mirza Junaid Ahmad ${ }^{1}$ and Kyung-Sook Choi ${ }^{2, *}$ (D) \\ 1 Department of Agricultural Civil Engineering, Kyungpook National University, Daegu 41566, Korea; \\ wshh1212@naver.com (G.-H.C.); agri.junaid1205@gmail.com (M.J.A.) \\ 2 Department of Agricultural Civil Engineering, Institute of Agricultural Sciences \& Technology, \\ Kyungpook National University, Daegu 41566, Korea \\ * Correspondence: ks.choi@knu.ac.kr; Tel.: +82-53-950-5731
}

Citation: Cho, G.-H.; Ahmad, M.J.; Choi, K.-S. Water Supply Reliability of Agricultural Reservoirs under Varying Climate and Rice Farming Practices. Water 2021, 13, 2988.

https://doi.org/10.3390/w13212988

Academic Editor:

José Gutiérrez-Pérez

Received: 23 September 2021

Accepted: 20 October 2021

Published: 22 October 2021

Publisher's Note: MDPI stays neutral with regard to jurisdictional claims in published maps and institutional affiliations.

Copyright: (c) 2021 by the authors. Licensee MDPI, Basel, Switzerland. This article is an open access article distributed under the terms and conditions of the Creative Commons Attribution (CC BY) license (https:// creativecommons.org/licenses/by/ $4.0 /)$.

\begin{abstract}
Technological development and climate change dictate farming practices, which can directly affect irrigation water requirement and supply. In this article, the water supply reliability (WSR) of 62 major Korean agricultural reservoirs was comprehensively evaluated for varying climate and farming practices. Field surveys identified the recent divergence from standard rice farming practices and a 45-year daily weather data set (1973-2017) was examined to understand the phenomenon of climate change. Effective rainfall increments mitigated the imminent surges in rice irrigation water requirements driven by warming-led accelerated crop evapotranspiration rates; therefore, climate change marginally influenced the WSR of selected reservoirs. The transplanting period and associated water consumption were the primary deviations from standard rice farming practices. A significantly prolonged transplanting period seriously compromised the WSR of agricultural reservoirs and the maximum number of unsafe reservoirs was detected for a 24-day increase in the transplanting period. A watershed/irrigated area ratio of less than 2.5 was the lower threshold below which all the reservoirs had unsafe WSR regardless of the climate change and/or farming practices. Recent variations in farming practices were the primary cause of reservoir failure in maintaining the WSR.
\end{abstract}

Keywords: climate change; rice farming practices; irrigation water requirement; water supply reliability; agricultural reservoirs

\section{Introduction}

Climate change is a major dilemma faced by humanity during the last few decades, and it has serious ramifications for water resource management, irrigation water supplies, and crop water demands. Hydrologic implications of climate change brunt are frequently witnessed including extreme events such as heavy rainfalls, heat waves, floods and droughts [1-6]. The climate change predicament is distinctively severe in Korea compared to the rest of the world, and spatiotemporal temperature and rainfall variation are reshaping the watershed environment, runoff generation, irrigation water supplies and crop water demands [7,8]. During the last five years, average temperature and rainfall in Korea have increased by $0.6{ }^{\circ} \mathrm{C}$ and decreased by $150 \mathrm{~mm}$, respectively, compared to the last three decades [7]. Agricultural reservoirs are the primary irrigation source to sustain rice production against rampant droughts, which is also the focal point of agricultural management and development policies of the Korean government [9-11].

Rainfall and runoff discrepancies have exacerbated the agricultural drought vulnerability of Korea, compromising the water supply reliability (WSR) of reservoirs [10]. Severe droughts struck Korea every 6-7 years during the 20th century; however, after 2000, there have been consecutive droughts during 2013-2018 [12]. The decline in monsoon rainfall in the rice season is the main cause of drought, and has resulted in restricted runoff gen- 
eration in the watershed, and the inability of agricultural reservoirs to meet irrigation demands [4,13].

Conventionally, water resource structures including reservoirs were designed to meet the water demands associated with a drought of specific recurrence interval, but the climateinduced uncertainty in the occurrence probabilities of the extreme event has rendered this approach questionable [14]. Numerous studies have simulated the reservoir water balance to evaluate the resilience, vulnerability, reliability and sustainability of water supplies from the reservoirs by coupling hydrological models with bias-corrected future climate change projections [15-20]. Green and Weatherhead [21] suggested that the irrigation reservoir design should be based on a probabilistic evaluation of climate change projections which produces a range of possible outcomes, instead of the deterministic approach which usually yields a single possible outcome. The top-down approach tackles the future climate change projections by further elaborating on the future economic, technological and social development; however, the approach lacks the ability to incorporate the extreme climate events when projecting the water demand and consumption patterns [22]. The bottom-up approach circumvents the uncertainties in climate change projections by defining a set of hydro-meteorological exposure states or scenarios under which a water resource system would perform satisfactorily $[14,22,23]$.

The design criterion for Korean agricultural reservoirs is to meet the water requirements of a 10-year frequency drought, but most old reservoirs often fail to maintain a reliable water supply due to seasonal rainfall variations or lack of proper care and maintenance $[4,24]$. Hence, the design criteria for the agricultural reservoir should be re-evaluated and revised to accommodate the climate-instigated uncertainties in the upstream watershed runoff generation and downstream water demands $[25,26]$.

The climate vulnerability of Korea has been extensively examined by identifying the design water requirements for a 10-year return period drought under the historic [27] and future climate change trends $[4,9,11,28]$, development and application of an irrigation vulnerability assessment model for agricultural reservoirs [1,24,29], meteorological and agricultural drought risk assessment [13,24,30], and improving the monitoring and management of reservoir operation to stabilize the irrigation water supply [31,32]. In addition to the hydrological repercussions, climate change is also transforming rice farming practices, crop growth periods, and yields [33], and irrigation water supply from agricultural reservoirs is highly dependent on the operational and physical characteristics of the irrigation district dictated by agricultural practices [25].

The above-mentioned studies investigated the consequences of climate change without incorporating the varying rice farming practices due to rapid farm mechanization, socioeconomic development, changing food preferences and prevalent trends in the farmer population over the past several decades. Cho et al. [4] examined the WSR of agricultural reservoirs in Korea in the context of change in climate and rice farming practices, but their study was limited to only 12 reservoirs.

In this study, we examined the WSR of 62 major agricultural reservoirs by simultaneously incorporating the variations in climate and rice farming practices based on the most recent survey findings. Rice crop evapotranspiration $\left(\mathrm{ET}_{\mathrm{C}}\right)$, irrigation water requirement (IWR), and annual maximum water demand (AMWD) were estimated from the paddy and reservoir water balance models. Finally, the irrigation water supplies (IWS) and effective storage capacities of the reservoirs were compared with the IWR and AMWD, respectively, to identify the WSR of the reservoirs under the influence of varying climate and farming practices in Korea.

\section{Materials and Methods}

\subsection{Estimation of Irrigation Water Requirement}

In Korea, nursery transplanting to ponded fields is the most common rice cultivation practice, and IWR is the depth of water required to compensate for water losses as $\mathrm{ET}_{\mathcal{C}}$ and soil infiltration, excluding the rainwater contribution as effective rainfall $(E R)[9,11]$. 
Paddy water balance model requires water consumption data during nursery raising and transplanting in addition to the reference evapotranspiration $\left(\mathrm{ET}_{\mathrm{o}}\right)$, crop coefficient and soil infiltration rates $[4,9]$.

Rice $\mathrm{ET}_{\mathrm{c}}$ was estimated as a product of $\mathrm{ET}_{\mathrm{o}}$ from the Modified Penman equation [34] and the crop coefficient [35], and IWR was estimated by adding the net irrigation water requirement (NIWR) and conveyance loss minus the ER. The water depth required for nursery preparation $\left(\mathrm{NIWR}_{\mathrm{np}}\right)$, nursery raising $\left(\mathrm{NIWR}_{\mathrm{n}}\right)$, nursery transplanting $\left(\mathrm{NIWR}_{\mathrm{t}}\right)$ and growing season $\mathrm{ET}_{\mathrm{C}}$ loss $\left(\mathrm{NIWR}_{\mathrm{g}}\right.$ ) were summed to estimate the IWR [36]. The NIWR is a function of $\mathrm{ET}_{\mathrm{c}}$, soil infiltration rate, and water requirement for crop management $\left(\mathrm{NIWR}_{\mathrm{np}}+\mathrm{NIWR}_{\mathrm{t}}\right)$. The soil infiltration rate and conveyance losses were $5 \mathrm{~mm} / \mathrm{d}[1,11]$ and $15 \%$ [36], respectively. The required ponding depth that must be maintained in the nursery (NPW in Equation (2)) and the rice field (TW in Equation (4)) was $140 \mathrm{~mm}$ [8,11]. Different components of the paddy IWR were calculated as follows:

$$
\mathrm{IWR}=\sum \mathrm{NIWR} \div\left(1-\frac{\mathrm{L}}{100}\right)
$$

where IWR = irrigation water requirement $(\mathrm{mm}), \mathrm{NIWR}=$ net IWR $(\mathrm{mm})$, and $\mathrm{L}=$ conveyance loss $(\%)$.

$$
\begin{gathered}
\mathrm{NIWR}_{n p}=\left(\mathrm{I}-\mathrm{ER}+\frac{\mathrm{NPW}}{\mathrm{D}_{\mathrm{np}}}\right) \times \frac{\mathrm{A}_{\mathrm{n}}}{\mathrm{A}} \\
\mathrm{NIWR}_{\mathrm{n}}=\left(\mathrm{I}+\mathrm{ET}_{\mathrm{c}}-\mathrm{ER}\right) \times \frac{\mathrm{A}_{\mathrm{n}}}{\mathrm{A}} \\
\mathrm{NIWR}_{\mathrm{t}}=\left[\left(\mathrm{I}+\mathrm{ET}_{\mathrm{c}}-\mathrm{ER}\right) \times\left(\frac{\mathrm{A}_{\mathrm{n}}}{\mathrm{A}}\right)\right]+\left[\left(\mathrm{I}+\mathrm{ET}_{\mathrm{c}}-\mathrm{ER}+\frac{\mathrm{TW}}{\mathrm{D}_{\mathrm{t}}}\right) \times\left(\frac{\mathrm{A}_{\mathrm{t}}}{\mathrm{A}}\right)\right] \\
\mathrm{NIWR}_{\mathrm{g}}=\left(\mathrm{I}+\mathrm{ET}_{\mathrm{c}}-\mathrm{ER}\right) \times \frac{\mathrm{A}_{\mathrm{t}}}{\mathrm{A}}
\end{gathered}
$$

where I = Infiltration $(\mathrm{mm}), \mathrm{ER}=$ effective rainfall $(\mathrm{mm}), \mathrm{NPW}=$ nursery preparation water (crop management water) $(\mathrm{mm}), \mathrm{D}_{\mathrm{np}}=$ days of nursery preparation (day), $\mathrm{A}_{\mathrm{n}}=$ nursery area (ha), $\mathrm{A}=$ rice crop area (ha), $\mathrm{ET}_{\mathrm{c}}=$ crop evapotranspiration, $\mathrm{TW}=$ transplanting water (crop management water) $(\mathrm{mm}), \mathrm{D}_{\mathrm{t}}=$ days of transplanting period (day), $\mathrm{A}_{\mathrm{t}}=$ transplanting area (ha), $\mathrm{np}=$ nursery preparation period (day), $\mathrm{n}=$ nursery period (day), $\mathrm{t}=$ transplanting period (day), and $\mathrm{g}=$ growing period (day)

During most of the rice season, the soil remains saturated in ponded fields and incident rainfall directly contributes to the ponding depth [9], therefore ER is the rainfall that contributes to ponding depth excluding the surface runoff. We used the freeboard model of ER estimation to simulate the ponding depth in the rice field $[8,11]$. The upper and lower ponding thresholds were $80 \mathrm{~mm}$ and $20 \mathrm{~mm}$ [37] and Equations (6)-(10) were used for ER calculation as follows:

$$
\begin{gathered}
\mathrm{PD}_{\mathrm{t}}=\mathrm{PD}_{\mathrm{t}-1}+\mathrm{MW}_{\mathrm{t}}+\mathrm{P}_{\mathrm{t}}-\mathrm{ET}_{\mathrm{c}, \mathrm{t}}-\mathrm{I}_{\mathrm{t}}-\mathrm{SR}_{\mathrm{t}} \\
\mathrm{SR}_{\mathrm{t}}=0 \text { for } \mathrm{PD}_{\mathrm{t}} \leq 80 \\
\mathrm{ER}_{\mathrm{t}}=\mathrm{P}_{\mathrm{t}} \text { for } \mathrm{SR}_{\mathrm{t}}=0 \\
\mathrm{SR}_{\mathrm{t}}=\mathrm{P}_{\mathrm{t}}-\left(80-\mathrm{PD}_{\mathrm{t}-1}\right) \text { for } \mathrm{PD}_{\mathrm{t}}>80 \\
\mathrm{ER}_{\mathrm{t}}=\mathrm{P}_{\mathrm{t}}-\mathrm{SR}_{\mathrm{t}} \text { for } \mathrm{SR}_{\mathrm{t}}>0
\end{gathered}
$$

where $\mathrm{PD}=$ ponding depth $(\mathrm{mm}), \mathrm{MW}=$ crop management water $(\mathrm{mm}), \mathrm{P}=$ precipitation $(\mathrm{mm}), \mathrm{SR}=$ surface runoff $(\mathrm{mm})$, and $\mathrm{t}=$ daily time step.

\subsection{Data Collection of the Changed Paddy Transplanting Period}

In Korea, agricultural reservoirs were initially designed to ensure water supply according to standard farming practices and climate-dependent rice $\mathrm{ET}_{\mathrm{c}}$ prevalent at the 
time of reservoir construction. However, Korean rice farming has evolved due to rapid urbanization, socioeconomic development and industrialization. The farmer population has declined and modern agricultural machinery has gradually replaced traditional laborintensive rice farming. Rapid climate change and poor management of old water resource infrastructure have altered the standard farming and water management/application practices [4]. A comprehensive evaluation of rice IWR and WSR in the context of recent changes in climate and farming practices is imperative not only for efficient reservoir operation but also for revising the design criteria of agricultural reservoirs.

The Korea Rural Corporation (KRC) surveyed in 2020 to collect data on current field-scale rice farming practices. Deviations from standard rice farming practices were identified based on the opinions of 120 farmers being part of the Korea Rice Organization. Approximately $97 \%$ of farmers used the nursery transplanting method while the remaining $3 \%$ used both transplanting and direct seeding methods for rice cultivation. Therefore, in this study, it was assumed that all farmers use the nursery transplanting method of rice cultivation.

The survey findings were categorized in four transplanting scenarios listed in Tables 1 and 2. The 'standard rice cropping period' in Table 1 refers to the conditions under which the reservoirs were designed for optimal operation [38], and Scenarios A, B and C in Table 2 show current rice farming practices based on the survey findings. Except for a significantly prolonged transplanting period, important rice growth stages were similar to the standard cropping period. The standard transplanting period was 20 days and the corresponding transplanting water requirement was $140 \mathrm{~mm}$, resulting in a water consumption rate of $7 \mathrm{~mm} /$ day. The standard transplanting period was prolonged by 8-24 days and the corresponding transplanting water requirement was increased by $56-168 \mathrm{~mm}$. Adaptation of modern hybrid seeds and cultivation methods such as double cropping and direct seeding could explain the expansion in the current transplanting period.

Table 1. Standard rice cropping period in Korea [38].

\begin{tabular}{ccccc}
\hline \multirow{2}{*}{ Region } & \multicolumn{4}{c}{ Stage of Transplanting Paddy Cultivation } \\
\cline { 2 - 5 } & Nursery Preparation & Nursery Raising & Transplanting Period & Growing Season \\
\hline Central & $17-20$ April & 20 April-1 June & 20 May-10 June & 1 June-10 September \\
\hline
\end{tabular}

Table 2. Currently changed rice transplanting periods based on the Korea Rural Corporation survey [39].

\begin{tabular}{cccc}
\hline Classification & Transplanting Period & Transplanting Days & $\begin{array}{c}\text { Transplanting Water } \\
\text { Requirement (mm) }\end{array}$ \\
\hline Scenario A & 12 May-9 June & 28 & 196 \\
\hline Scenario B & 8 May-13 June & 36 & 252 \\
\hline Scenario C & 4 May-17 June & 44 & 308 \\
\hline
\end{tabular}

\subsection{Evaluation of Water Supply Reliability of Agricultural Reservoir}

Modelling the agricultural reservoir operation involves examining the runoff generation in the watershed based on the rainfall characteristics and irrigation district's water demands derived from the paddy water balance. Reservoir storage capacity is also critical in ensuring reliable and timely water supply according to the paddy IWR at different growth stages $[4,10]$. In this study, a water balance approach was used to model reservoir operation after accounting for water supplies, a function of water inflows from the watershed into the reservoir and water delivered from irrigation facilities, and water demands from irrigation districts $[4,25,40]$.

The WSR represents the relationship between the effective storage capacity of agricultural reservoirs and AMWD based on rice IWR in the command areas. We performed a daily reservoir water balance according to the KRC guideline [37] to estimate the AMWD. 
Baseflow contribution and downward seepage from the reservoir floor were not considered because of their negligible influence on overall reservoir water balance $[4,37,40]$ represented by Equations (11)-(14) as:

$$
\begin{gathered}
\mathrm{S}_{\mathrm{t}}=\mathrm{S}_{\mathrm{t}-1}+\mathrm{I}_{\mathrm{t}}+\mathrm{U}_{\mathrm{t}}+\mathrm{P}_{\mathrm{t}}-\left(\mathrm{IWR}_{\mathrm{t}}+\mathrm{O}_{\mathrm{t}}+\mathrm{E}_{\mathrm{t}}+\mathrm{G}_{\mathrm{t}}+\mathrm{D}_{\mathrm{t}}\right) \\
\mathrm{P}_{\mathrm{t}}=\mathrm{C}_{\mathrm{p}} \times \mathrm{PS}_{\mathrm{t}} \times \mathrm{RA}_{\mathrm{f}} \\
\mathrm{E}_{\mathrm{t}}=\mathrm{C}_{\mathrm{E}} \times \mathrm{RA}_{\mathrm{f}} \times \mathrm{E}_{\mathrm{v}} \times \mathrm{P}_{\mathrm{C}} \\
\mathrm{O}_{\mathrm{t}}=\mathrm{S}_{\mathrm{t}}-\mathrm{S}_{\mathrm{f}} \text { for } \mathrm{S}_{\mathrm{t}}>\mathrm{S}_{\mathrm{f}}
\end{gathered}
$$

where $\mathrm{S}=$ reservoir storage $\left(\mathrm{m}^{3}\right), \mathrm{I}=$ watershed inflow $\left(\mathrm{m}^{3}\right), \mathrm{U}=$ underground inflow $\left(\mathrm{m}^{3}\right)$, $\mathrm{P}=$ precipitation at the reservoir surface $\left(\mathrm{m}^{3}\right), \operatorname{IWR}=$ irrigation water requirement $\left(\mathrm{m}^{3}\right)$, $\mathrm{O}=$ spillway overflow $\left(\mathrm{m}^{3}\right), \mathrm{E}=$ reservoir surface evaporation $\left(\mathrm{m}^{3}\right), \mathrm{G}=$ underground infiltration $\left(\mathrm{m}^{3}\right), \mathrm{D}=$ reservoir infiltration $\left(\mathrm{m}^{3}\right), \mathrm{C}_{\mathrm{P}}=$ unit conversion coefficient (10), PS $=$ incident precipitation at the reservoir surface $(\mathrm{mm}), \mathrm{RA}_{\mathrm{f}}=$ full surface water level in reservoir (ha), $\mathrm{C}_{\mathrm{E}}=$ unit conversion coefficient $(0.001), \mathrm{E}_{\mathrm{V}}=$ watershed evaporation $(\mathrm{mm})$, $P_{c}=$ Pan coefficient, $S_{f}=$ full water storage $\left(\mathrm{m}^{3}\right)$, and $t=$ daily time step.

In Korea, the WSR of agricultural reservoirs is evaluated by comparing the effective storage capacity and the AMWD for a 10-year return period drought $[4,11]$. The Gumbel frequency distribution was used to estimate the AMWD associated with various return periods, and reservoirs with inadequate storage capacities were considered unsafe. The Chow frequency factor method [11,41] was used for the estimation of AMWD as follows:

$$
\mathrm{X}_{\mathrm{t}}=\mathrm{X}_{\mathrm{a}}+\mathrm{k} \times \delta_{\mathrm{n}-1}
$$

where $X_{t}=$ annual maximum water demand (AMWD) for t-year return period $\left(\mathrm{m}^{3}\right)$, $\mathrm{X}_{\mathrm{a}}=$ average $\mathrm{AMWD}\left(\mathrm{m}^{3}\right), \mathrm{k}=$ frequency coefficient, and $\delta_{\mathrm{n}-1}=$ standard deviation of AMWD.

The primary function of an agricultural reservoir is to store water that can be supplied according to the IWR at critical growth stages. KRC provided the eight years (2011-2017) of water depth data released by eight major reservoirs in the study area, which was converted to IWS using Equations (16) and (17). The important features of the reservoirs selected for the IWS calculation are listed in Table 3. We compared monthly IWR and IWS to evaluate the reservoir storage capacity. The cross-sectional area and the water velocity in the irrigation canal were used for the IWS calculation as follows:

$$
\begin{gathered}
\text { IWS }=\frac{A_{\mathrm{S}} \times \mathrm{V}_{\mathrm{S}}}{\mathrm{A}} \times \mathrm{C} \\
\mathrm{V}_{\mathrm{S}}=\frac{1}{\mathrm{n}} \times \mathrm{R}^{\frac{2}{3}} \times \mathrm{I}^{\frac{1}{2}}
\end{gathered}
$$

where IWS = irrigation water supply $(\mathrm{mm}), \mathrm{A}_{\mathrm{s}}=$ sectional area of starting point principal water conveyance on reservoir $\left(\mathrm{m}^{2}\right), \mathrm{Vs}=$ velocity of water $(\mathrm{m} / \mathrm{s}), \mathrm{A}=$ irrigated area $(\mathrm{ha})$, $\mathrm{C}=$ unit conversion coefficient, $\mathrm{n}=$ Manning's roughness coefficient, $\mathrm{R}=$ hydraulic radius $(\mathrm{m})$, and I = channel slope.

Table 3. Selected reservoirs for the estimation of irrigation water supply.

\begin{tabular}{ccccc}
\hline Reservoir Name & Command Area (ha) & Watershed Area (ha) & $\begin{array}{c}\text { Effective Storage } \\
\text { Capacity (10 } \mathbf{~ m}^{\mathbf{3}} \text { ) }\end{array}$ & Metrological Station \\
\hline Gohyeon & 180.6 & 3500 & 1963.2 & Uiseong \\
Dalchang & 540 & 5630 & 8649.1 & Daegu \\
Seongju & 319.3 & 1750 & 4602.8 & Gumi \\
Geumgye & 560.7 & 2425 & 5271 & Mungyeong \\
Hwagok & 288.2 & 955 & 1521.8 & Youngju \\
Maehwa & 176.6 & 5620 & 2553.7 & Yeongdeok \\
Ansim & 179.5 & 850 & 1577.4 & Pohang \\
Dangji & 114.8 & 840 & 1844 & Yeongcheon \\
\hline
\end{tabular}




\subsection{Study Area and Climate Variability}

In Korea, agriculture consumes approximately $47 \%$ of the water resources of which rice is the dominant consumer, and a large portion of total farmland is dedicated for rice cultivation annually $[4,10]$. This study focuses on southern region agricultural reservoirs located in the Kyungbuk province for impact assessment of climate change and farming practices on the WSR. We selected 62 reservoirs managed by the KRC (Figure 1) and each had more than one million tons of storage capacity. Table 4 presents the specifications of the selected reservoirs including watershed area, command area, effective storage capacity and meteorological station.

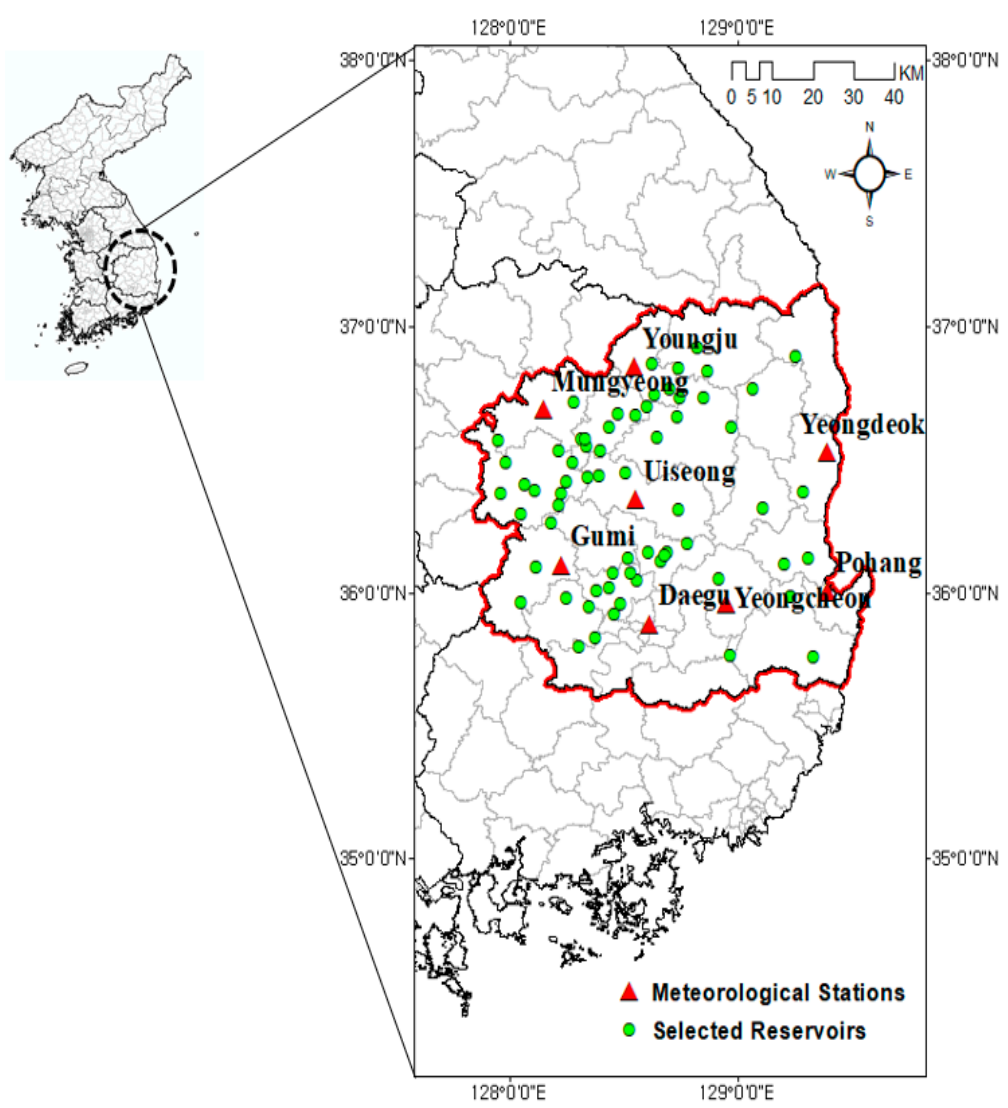

Figure 1. Locations of selected agricultural reservoirs and meteorological stations in the study area.

Table 4. Characteristics of the selected agricultural reservoirs in this study.

\begin{tabular}{|c|c|c|c|c|c|}
\hline KRC Branch & $\begin{array}{l}\text { Number of } \\
\text { Reservoirs }\end{array}$ & $\begin{array}{l}\text { Command Area } \\
\text { (ha) }\end{array}$ & $\begin{array}{l}\text { Watershed Area } \\
\text { (ha) }\end{array}$ & $\begin{array}{l}\text { Effective Storage Capacity } \\
\qquad\left(10^{3} \mathrm{~m}^{3}\right)\end{array}$ & $\begin{array}{l}\text { Meteorological } \\
\text { Station }\end{array}$ \\
\hline Uiseong & 3 & 368.1 & 1951.0 & 5043.1 & \multirow[b]{2}{*}{ Uiseong } \\
\hline Cheongsong & 4 & 160.7 & 1603.8 & 2348.6 & \\
\hline Chilgok & 3 & 175.0 & 1718.3 & 1522.6 & \multirow{3}{*}{ Daegu } \\
\hline Dalseong & 4 & 235.7 & 2747.7 & 3179.7 & \\
\hline Gyeongsan & 9 & 135.3 & 637.6 & 1686.2 & \\
\hline Gumi & 7 & 301.1 & 1114.6 & 2382.2 & \multirow{3}{*}{ Gumi } \\
\hline Seongju & 3 & 1766.1 & 7956.0 & $11,344.2$ & \\
\hline Yecheon & 1 & 159.2 & 910.0 & 1666.6 & \\
\hline Mungyeong & 2 & 1684.6 & 5030.0 & $13,134.3$ & \multirow[t]{2}{*}{ Mungyeong } \\
\hline Sangju & 6 & 430.8 & 3246.8 & 3128.9 & \\
\hline Youngju & 4 & 358.9 & 2051.8 & 3091.4 & Youngju \\
\hline Yeongdeok & 3 & 494.9 & 3510.0 & 4015.6 & Yeongdeok \\
\hline Pohang & 2 & 269.3 & 1504.3 & 3868.7 & \multirow{2}{*}{ Pohang } \\
\hline Gyeongju & 7 & 307.0 & 1273.0 & 1981.5 & \\
\hline Yeongcheon & 4 & 159.2 & 910.0 & 1454.4 & Yeongcheon \\
\hline Total & 62 & & & & \\
\hline
\end{tabular}


The Korean Meteorological Administration provided a daily data set of mean temperature $\left(\mathrm{T}_{\text {mean }}\right)$, relative humidity, wind speed, solar radiation, and precipitation $(\mathrm{P})$ for the 45 years from 1973 to 2017. Non-parametric Mann-Kendall test (MK test) and Sen's slope estimator $[42,43]$ were used to estimate the monthly, seasonal and annual trends in the $\mathrm{T}_{\text {mean }}$ and $\mathrm{P}$ data during 1973-2017. The climate data set was divided into three time slices of 15 years: TS1 (1973-1987), TS2 (1988-2002) and TS3 (2003-2017), and variations in rice seasonal and annual $\mathrm{T}_{\text {mean }}$ and $\mathrm{P}$ data were examined to identify shifts in average climatology of the study area during each time slice. Rice IWR and WSR of agricultural reservoirs were simulated for the transplanting scenarios during each time slice. Reservoirs at risk of failing to supply water against the AMWD of a 10-year frequency drought were identified for each transplanting scenario and time slice.

\section{Results and Discussion}

\subsection{Climate Variability of the Study Areas}

The non-parametric MK test for $\mathrm{T}_{\text {mean }}$ during the study period (1973-2017) detected significant $(\alpha=5 \%$ and $1 \%$ ) climate warming across the study area except for Mungyeong, where the annual $\mathrm{T}_{\text {mean }}$ declined non-significantly $(\alpha=10 \%)$ (Table 5). Annual $\mathrm{T}_{\text {mean }}$ $\left(12.6^{\circ} \mathrm{C}\right)$ fluctuated between $10-16{ }^{\circ} \mathrm{C}$ in the study area, while Pohang and Uiseong had the highest $\left(14.2^{\circ} \mathrm{C}\right)$ and lowest $\left(11.4{ }^{\circ} \mathrm{C}\right)$ annual $\mathrm{T}_{\text {mean }}$, respectively. Climate warming rates were notably prominent in Gumi, Daegu and Pohang where the annual $\mathrm{T}_{\text {mean }}$ trends were highly significant $(\alpha=1 \%)$ (Table 5).

Table 5. Sen's slope of monthly, seasonal and annual mean temperature $\left(\mathrm{T}_{\text {mean }}\right)$ and cumulative rainfall $(\mathrm{P})$ during 1973-2017.

\begin{tabular}{|c|c|c|c|c|c|c|c|c|}
\hline \multirow{2}{*}{ Duration } & \multicolumn{8}{|c|}{ Meteorological Station } \\
\hline & Uiseong & Daegu & Gumi & Mungyeong & Yeongju & Yeongdeok & Pohang & Yeongcheon \\
\hline \multicolumn{9}{|c|}{$\mathrm{T}_{\text {mean }}\left({ }^{\circ} \mathrm{C} /\right.$ year $)$} \\
\hline April & 0.0107 & $0.0374^{* *}$ & $0.0469^{* *}$ & -0.0091 & 0.0220 & 0.0165 & $0.0374 * *$ & $0.0201+$ \\
\hline May & $0.0259^{* *}$ & $0.0474^{* *}$ & $0.0573^{* *}$ & -0.0009 & 0.0296 ** & 0.0294 * & $0.0456^{* *}$ & 0.0296 ** \\
\hline June & $0.0168+$ & $0.0361 * *$ & $0.0404 * *$ & -0.0090 & $0.0205 *$ & $0.0230 *$ & $0.0361 * *$ & $0.0234 * *$ \\
\hline July & 0.0298 & 0.0367 & $0.0424 *$ & -0.0128 & 0.0138 & 0.0153 & 0.0341 & 0.0234 \\
\hline August & 0.0091 & 0.0129 & 0.0254 & $-0.0320+$ & 0.0018 & 0.0015 & 0.0232 & 0.0047 \\
\hline September & $0.0314 *$ & $0.0398^{* *}$ & $0.0536^{* *}$ & -0.0030 & $0.0257^{*}$ & 0.0096 & $0.0320^{* *}$ & $0.0231 *$ \\
\hline Rice Season & $0.0231 *$ & $0.0355^{* *}$ & $0.0436^{* *}$ & -0.0108 & $0.0186^{* *}$ & $0.0194 *$ & $0.0342^{* *}$ & $0.0232 * *$ \\
\hline Annual & $0.0227^{* *}$ & $0.0363^{* *}$ & $0.0482 * *$ & -0.0032 & $0.0282 * *$ & $0.0204^{* *}$ & $0.0358 * *$ & $0.0246^{* *}$ \\
\hline \multicolumn{9}{|c|}{ Rainfall (mm/year) } \\
\hline April & -0.2111 & -0.4310 & 0.1714 & -0.0353 & 0.3308 & 0.2045 & 0.0655 & 0.0091 \\
\hline May & 0.2250 & 0.1600 & 0.4200 & 0.1750 & 0.6423 & 0.0818 & 0.2471 & 0.1367 \\
\hline June & -1.3000 & -1.1977 & -1.1773 & -0.8878 & $-1.2067+$ & -0.8864 & -1.1355 & -1.3607 \\
\hline July & -0.0834 & 0.5811 & 0.4200 & 1.7750 & 2.2723 & 0.4750 & 0.2936 & 1.3638 \\
\hline August & 0.7503 & 1.7045 & 1.9121 & 1.5475 & 1.0849 & 0.1214 & 0.6403 & 1.1120 \\
\hline September & 0.6720 & 0.5487 & 0.4186 & 0.6253 & 0.5476 & 1.2136 & 0.6183 & 0.5480 \\
\hline Rice Season & -1.2500 & 0.6933 & 1.7385 & 2.5700 & 1.7316 & -0.6029 & -0.4526 & 0.5400 \\
\hline Annual & -1.1900 & 0.2976 & 2.4190 & 2.6947 & 3.2857 & -0.6613 & -0.1429 & 1.1789 \\
\hline
\end{tabular}

Note(s):,$+{ }^{* * *}$ represent the significance at $\alpha=10,5$ and $1 \%$, respectively, according to the MK test. The values without symbols are non-significant.

The rice-growing season $\mathrm{T}_{\text {mean }}\left(20.3^{\circ} \mathrm{C}\right)$ fluctuated between $17.9-23.4{ }^{\circ} \mathrm{C}$ across the study area, while Daegu and Yeongdeok had the highest $\left(21.7^{\circ} \mathrm{C}\right)$ and lowest $\left(19.7^{\circ} \mathrm{C}\right)$ $\mathrm{T}_{\text {mean }}$, respectively. The annual and seasonal $\mathrm{T}_{\text {mean }}$ change trends were almost similar and the highest and lowest warming rates were recorded at Gumi and Yeongju, respectively $(\alpha=1 \%)$ (Table 5). Variations in annual and seasonal $\mathrm{T}_{\text {mean }}$ and $\mathrm{P}$ during the time slices were also examined to comprehend the climate change phenomena. During the TS3, annual $\mathrm{T}_{\text {mean }}$ of $13.1^{\circ} \mathrm{C}$ was almost 0.5 and $1{ }^{\circ} \mathrm{C}$ higher than the respective TS2- and TS1- $\mathrm{T}_{\text {mean }}$ of $12.6^{\circ} \mathrm{C}$ and $12.2^{\circ} \mathrm{C}$ (Figure 2). The median annual $\mathrm{T}_{\text {mean }}$ and its interquartile range (IQR) 
of variability suggested a permanent warmer shift in the thermal regime featuring rampant heat wave incidents during the TS3.
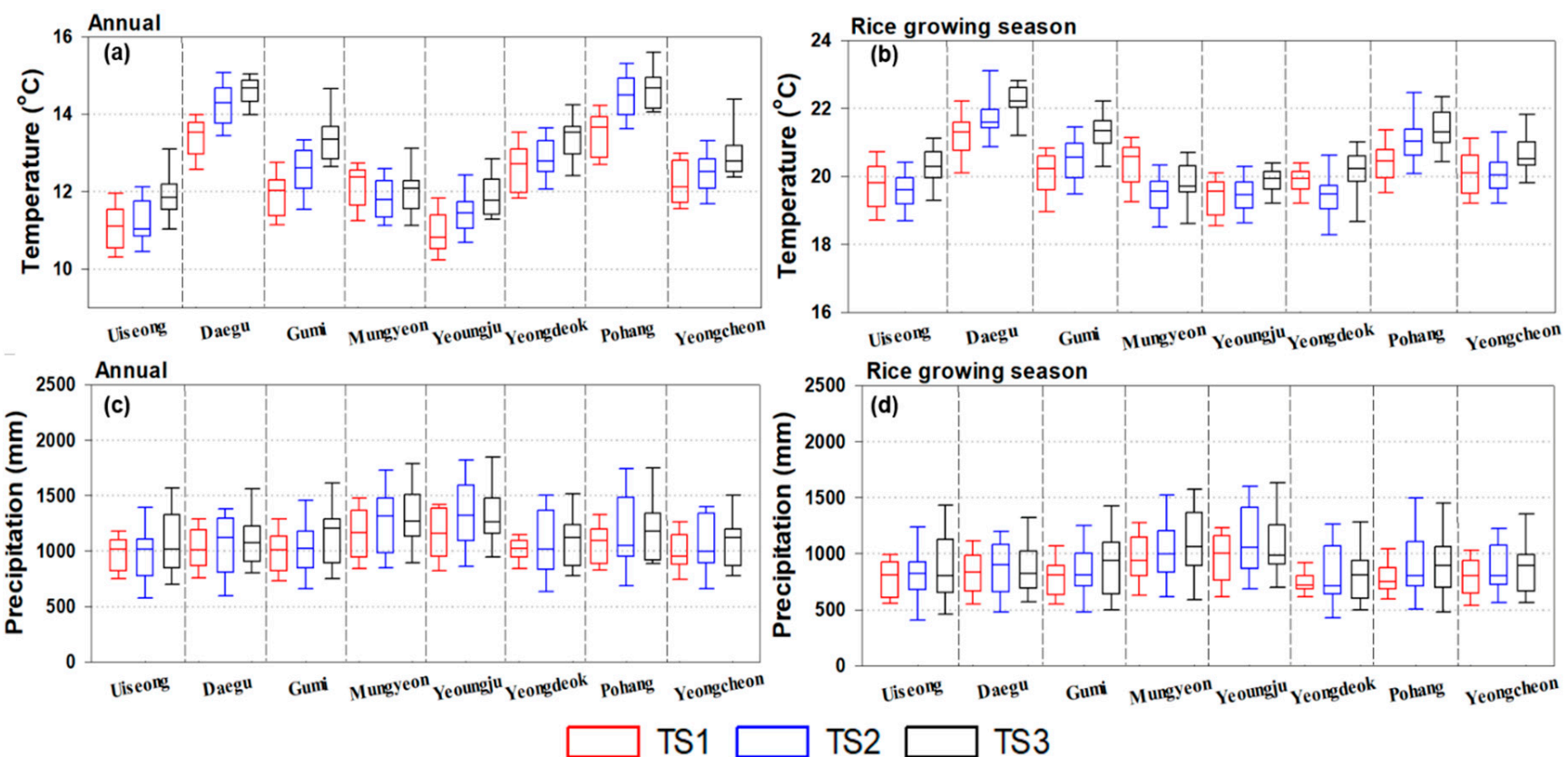

Figure 2. Evolution of annual and rice-growing season $(\mathbf{a}, \mathbf{b})$ mean temperature $\left(\mathrm{T}_{\text {mean }}\right)$ and $(\mathbf{c}, \mathbf{d})$ cumulative precipitation (P) during 1973-2017. The boxes in Figure 2 and below represent the interquartile ranges, the whiskers extend to the maximum and minimum values, and the horizontal lines inside boxes show median values.

The area received an annual average $\mathrm{P}$ of $1110 \mathrm{~mm}$, which fluctuated between 505-2098 mm. Annual cumulative P gradually increased over the last 45 years, as TS1, TS2, and TS3 received $1044 \mathrm{~mm}, 1120 \mathrm{~mm}$, and $1165 \mathrm{~mm}$ of $\mathrm{P}$, respectively, but the positive $P$ trends were mostly non-significant $(\alpha=10 \%)$ (Figure 2 and Table 5). The highest and lowest $\mathrm{P}$ values were $1264 \mathrm{~mm}$ and $1005 \mathrm{~mm}$, which were recorded in the Youngju and Uiseong areas, and the $\mathrm{P}$ trends were negative and positive, respectively. The 45-year averaged rice season cumulative $P$ was $889 \mathrm{~mm}$ and it fluctuated between $349-1799 \mathrm{~mm}$. The ratio of annual to rice season $P$ was almost constant in the time slices, suggesting that the seasonal and annual $\mathrm{P}$ was increasing at the same rate (Table 5). However, the median, maximum and minimum seasonal $\mathrm{P}$ values were higher than those of the annual scale, and the standard deviation of the seasonal $\mathrm{P}$ was 187.1 (TS1), 288.9 (TS2), and 311 (TS3) (Figure 2). This implied that the probability of seasonal scale occurrence of extreme $\mathrm{P}$ events has increased over the last 45 years.

The daily $\mathrm{T}_{\text {mean }}$ and $\mathrm{P}$ data were averaged to examine the monthly climate variability during the rice season which featured a single-peaked temperature regime. Lowest $\mathrm{T}_{\text {mean }}$ $\left(12.6^{\circ} \mathrm{C}\right)$ occurred in April, and it progressively reached the maximum values of $24.7^{\circ} \mathrm{C}$ and $25.1{ }^{\circ} \mathrm{C}$ in July and August, respectively, and finally dropped to $20.2{ }^{\circ} \mathrm{C}$ in September. Trend analysis of monthly $\mathrm{T}_{\text {mean }}$ showed significant warming ( $\alpha=5 \%$ and $\left.1 \%\right)$ during cooler months (April-June), whereas the $\mathrm{T}_{\text {mean }}$ during the warmer months (July-August) was non-significantly increasing (Table 5). The higher warming trend was detected at the start of the rice season as the TS3-T $\mathrm{T}_{\text {mean }}$ in April and May increased up to $0.6{ }^{\circ} \mathrm{C}$ or $4.4 \%$ compared to the TS1 and TS2 (Figure 3). 

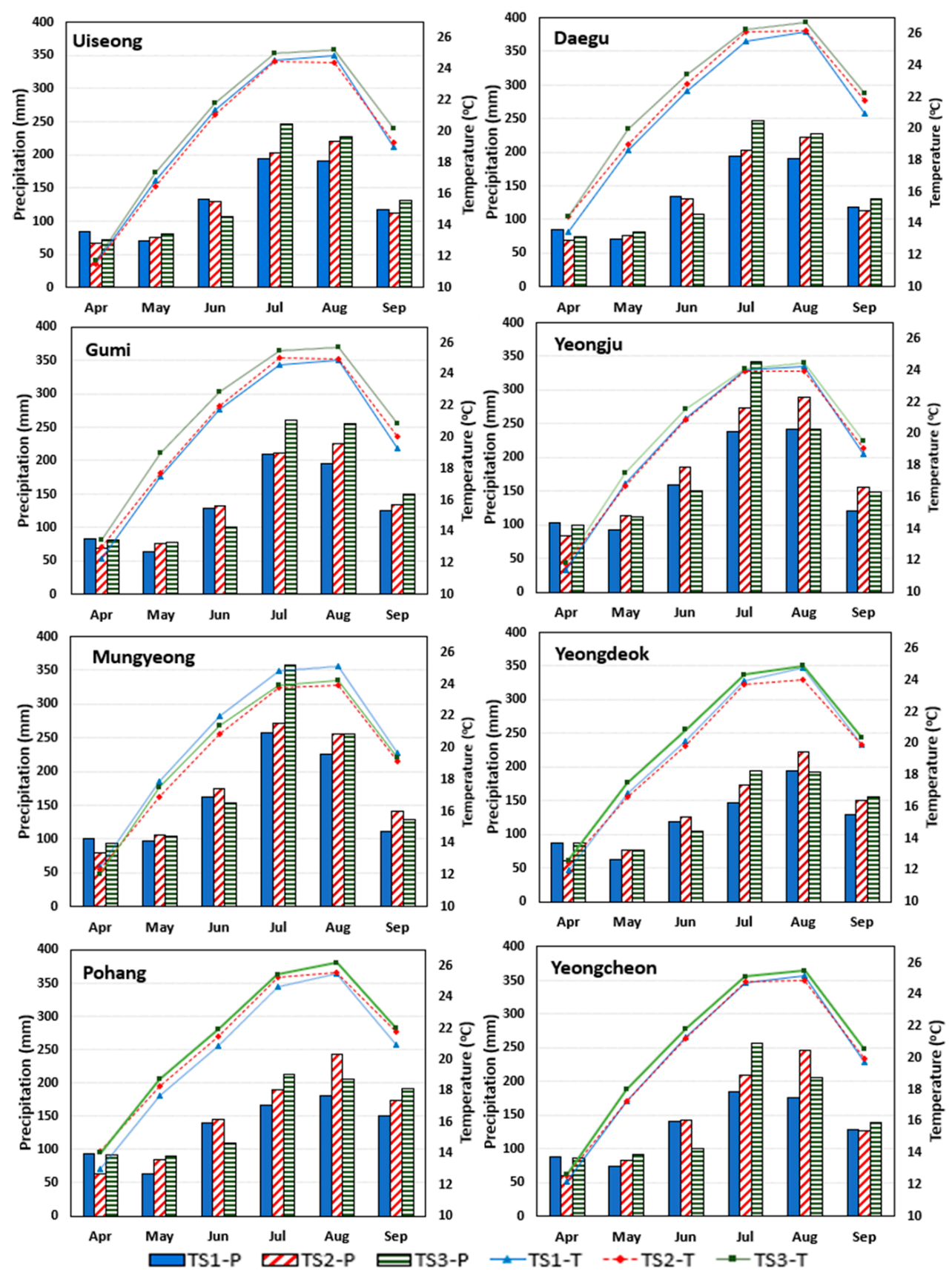

Figure 3. Monthly mean temperature $\left(\mathrm{T}_{\text {mean }}\right)$ and precipitation $(\mathrm{P})$ in the rice season averaged during the TS1 (1973-1987), TS2 (1988-2002) and TS3 (2003-2017) for the selected meteorological stations in this study.

Analysis of $\mathrm{P}$ data revealed that warmer months were also becoming wetter; for example, July and August, which had the highest $\mathrm{T}_{\text {mean, }}$ also received heavy $\mathrm{P}$. The rice season began with stable or slightly decreasing $\mathrm{P}$ that progressively intensified during the middle months, especially from July onward. During the study period, a warmer and wetter shift was detected in the average climatology of the study area (Table 5 and Figure 3).

The peak water demand period of the transplanting and booting stage coincided with June which was the warmest and driest month of the rice season. This implicates an impending mismatch between water demand and supply in June whereas the heavy $\mathrm{P}$ increments in July and August corresponding to the flood season in Korea. The seasonal patterns were shifting towards intense monsoon rainfalls accompanied by hotter and drier 
monthly transitions at the critical rice growth stages which could substantially alter the $\mathrm{ET}_{\mathrm{C}}$, IWR, IWS and WSR.

\subsection{Evapotranspiration and Irrigation Water Requirement}

Average rice $\mathrm{ET}_{\mathrm{C}}$ of the study area during the TS1 was $585 \mathrm{~mm}$ and it fluctuated in the range of 548-695 $\mathrm{mm}$. Climate warming gradually increased the rice $\mathrm{ET}_{\mathrm{C}}$ during the study period and the TS2- and TS3-ET ${ }_{\mathrm{c}}$ were $610 \mathrm{~mm}$ and $621 \mathrm{~mm}$, respectively. Table 6 presents the comparison of average rice $\mathrm{ET}_{\mathrm{C}}$ during TS1 with those during TS2 and TS3. The $\mathrm{T}_{\text {mean }}$ was the primary $\mathrm{ET}_{\mathrm{c}}$ determinant, as the Pohang and Uiseong regions with the respective highest and lowest $\mathrm{T}_{\text {mean }}$ had the highest and lowest $\mathrm{ET}_{\mathrm{C}}$. Although $\mathrm{ET}_{\mathrm{C}}$ was highly variable in the study area, the general increase rate of $\mathrm{ET}_{\mathrm{C}}$ was $42.3 \mathrm{~mm} /{ }^{\circ} \mathrm{C}$.

Table 6. Average seasonal cumulative ET $_{C}$ of rice during TS1 (1973-1987), TS2 (1988-1902), and TS3 (2003-2017) based on the daily data from the selected meteorological stations. The bold values show the absolute and percent change in rice $\mathrm{ET}_{\mathrm{C}}$ during the TS2 and TS3 compared to the TS1.

\begin{tabular}{|c|c|c|c|c|c|c|c|c|c|c|c|c|c|c|c|c|c|c|}
\hline \multirow{2}{*}{\multicolumn{2}{|c|}{ Time Slice }} & \multicolumn{17}{|c|}{ Meteorological Station } \\
\hline & & \multicolumn{2}{|c|}{ Uiseong } & \multicolumn{2}{|c|}{ Daegu } & \multicolumn{2}{|c|}{ Gumi } & \multicolumn{2}{|c|}{ Mungyeong } & \multicolumn{2}{|c|}{ Yeongju } & \multicolumn{2}{|c|}{ Yeongdeok } & \multicolumn{2}{|c|}{ Pohang } & \multicolumn{2}{|c|}{ Yeongcheon } & Average \\
\hline \multicolumn{2}{|c|}{ 1973-1987 } & \multicolumn{2}{|c|}{548} & \multicolumn{2}{|c|}{605} & \multicolumn{2}{|c|}{561} & \multicolumn{2}{|c|}{583} & \multicolumn{2}{|c|}{567} & \multicolumn{2}{|c|}{590} & \multicolumn{2}{|c|}{658} & \multicolumn{2}{|c|}{570} & 585 \\
\hline \multirow{2}{*}{$\begin{array}{c}1988- \\
2002\end{array}$} & $\underset{\left(a^{*}\right)}{\mathbf{m m}}$ & \multirow{2}{*}{620} & 72 & \multirow{2}{*}{687} & 81 & \multirow{2}{*}{569} & 8 & \multirow{2}{*}{569} & -14 & \multirow{2}{*}{574} & 7 & \multirow{2}{*}{596} & 5 & \multirow{2}{*}{687} & 28 & \multirow{2}{*}{582} & 11 & \multirow{2}{*}{$610 \stackrel{24}{5.1}$} \\
\hline & $\begin{array}{c}\% \\
\left(b^{*}\right)\end{array}$ & & 13 & & 13 & & 1.5 & & -2.5 & & 1.3 & & 0.9 & & 4.3 & & 2 & \\
\hline \multirow{2}{*}{$\begin{array}{c}2003- \\
2017\end{array}$} & $\frac{\mathrm{mm}}{\left(\mathrm{a}^{*}\right)}$ & \multirow{2}{*}{631} & 83 & \multirow{2}{*}{695} & 90 & \multirow{2}{*}{582} & 21 & \multirow{2}{*}{582} & -1 & \multirow{2}{*}{590} & 23 & & 14 & & 37 & & 21 & 36 \\
\hline & $\begin{array}{c}\% \\
\left(b^{*}\right)\end{array}$ & & 15 & & 15 & & 3.8 & & -0.2 & & 4.2 & & 2.4 & & 5.6 & & 3.7 & 7.1 \\
\hline
\end{tabular}

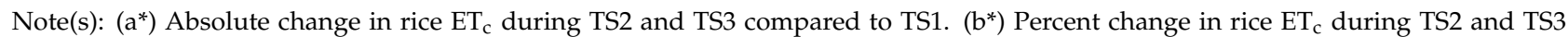
compared to TS1.

Equation (1) was used to simulate the IWR from paddy water balance under the transplanting scenarios. Rice $\mathrm{ET}_{\mathrm{C}}$ was unchanged under the transplanting scenarios, but they influenced the IWR which assimilated the water requirements to compensate for $\mathrm{ET}_{\mathrm{C}}$ and land preparation through puddling (Figure 4). The standard IWR of $755 \mathrm{~mm}$ increased to $823.3 \mathrm{~mm}, 845.4 \mathrm{~mm}$, and $961.2 \mathrm{~mm}$ under the transplanting scenarios $\mathrm{A}$, $B$, and $C$, respectively. Heavy monsoon rainfall supplemented the warming-driven $\mathrm{ET}_{\mathrm{C}}$ increments and the IWR even decreased in the Uiseong, Mugyeong, and Pohang regions with notable $\mathrm{P}$ increments. The reason for this phenomenon is that, unlike $\mathrm{ET}_{\mathrm{C}}, \mathrm{IWR}_{\mathrm{S}}$ affected by $\mathrm{T}_{\text {mean }}$ and $\mathrm{P}$. Seasonal cumulative $\mathrm{P}$ gradually increased over time, resulting in improved rainwater availability as ER and a reduction in IWR. The Daegu had the highest IWR because of high $\mathrm{T}_{\text {mean }}$ and low $\mathrm{P}$, while Yeongju had minimum IWR due to lower $\mathrm{T}_{\text {mean }}$ and intense $\mathrm{P}$. These results implied that climate change had limited effects on the IWR increments and the prolonged transplanting period is the key driver of higher IWR witnessed during the recent years.

The IWS data for the selected reservoirs during the rice season were converted to water depths using Equations (16) and (17) to facilitate the comparison between the IWS and IWR. The average standard IWS (1086 mm) was 44\% higher than the corresponding IWR of $755 \mathrm{~mm}$. Similarly, for scenarios A, B, and C, the IWS was 32\%, 29\%, and 13\% higher than the respective IWR, showing that the IWS was best suited to satisfy the IWR under scenario $C$, while surplus water was being delivered to the rice fields in the other transplanting scenarios.

Figure 5 compares the average monthly P, IWR and IWS for the selected reservoirs under different transplanting scenarios. The incident $\mathrm{P}$ dictates the IWR, which drives the IWS from the reservoirs. The transplanting period during May and June, and the nursery period in April, had the maximum and minimum IWR and IWS, respectively. The peak IWR (277 mm) and IWS (340 mm) occurred in June, which had a significantly warmer 
and drier shift over the last 45 years. For scenarios A, B and C, the May standard IWR $(61 \mathrm{~mm})$ increased to $129 \mathrm{~mm}(110.4 \%), 145.8 \mathrm{~mm}(137.7 \%)$, and $164.8 \mathrm{~mm}(168.7 \%)$, and the June standard IWR (244 mm) increased to $255.9 \mathrm{~mm}(5.1 \%), 266.8 \mathrm{~mm}(9.6 \%)$ and $325.2 \mathrm{~mm}$ (33.6\%), respectively. The scenario-wise IWR variations were alarming for the regions featuring warmer and dryer climate shifts.
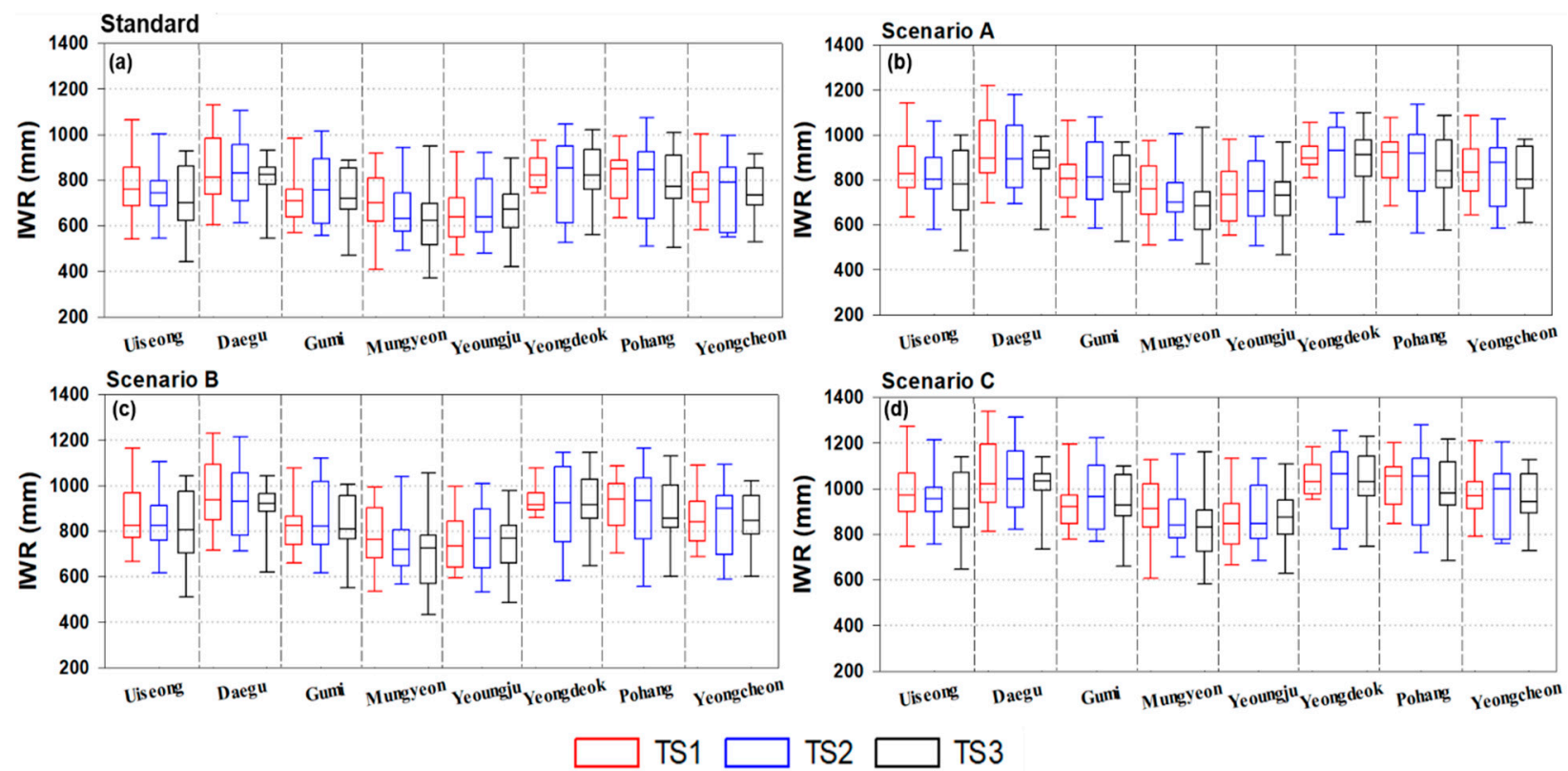

Figure 4. Variations in irrigation water requirement (IWR) depending on transplanting scenarios: (a) standard, (b) A, (c) B, and (d) C during the TS1 (1973-1987), TS2 (1988-2002) and TS3 (2003-2017). Description of the transplanting scenarios is provided in Table 2.

\subsection{Water Supply Reliability of Agricultural Reservoirs}

We compared the AMWD and effective storage capacities of the reservoirs during the time slices under the transplanting scenarios, and the reservoirs were classified as unsafe if these were unable to store the AMWD of the 10-year return period drought. Climate change negligibly influenced the WSR as most reservoirs had adequate storage capacities throughout the time slices, and of the selected 62 only 10,8 and 11 reservoirs were unsafe during TS1, TS2, and TS3, respectively (Figure 6). The higher seasonal ER counteracted the warming-induced $\mathrm{ET}_{\mathrm{C}}$ increments, resulting in stable IWR and AMWD across the time slices.

Reservoirs with large water storage capacities were able to store excess $P$ that was subsequently released during peak water demand periods. This phenomenon was evident in Daegu and Gumi areas where the agricultural reservoirs had relatively larger storage capacities. The transplanting scenarios seriously compromised the WSR of agricultural reservoirs and the maximum number of unsafe reservoirs was detected in scenario $C$, regardless of the time slices. For a specific transplanting scenario, the number of unsafe reservoirs progressively increased with time (Figure 6).

The watershed/irrigated area ratio was critical as the reservoirs with a high watershed/irrigated area ratio mostly had safe WSR regardless of the time slice and transplanting scenario. For example, of the 16 reservoirs in the Daegu region that had a large average watershed area and a small irrigated area, only one reservoir was unsafe. Conversely, out of the 30 reservoirs in Gumi with the small average watershed area and large irrigated area three reservoirs were unsafe. 

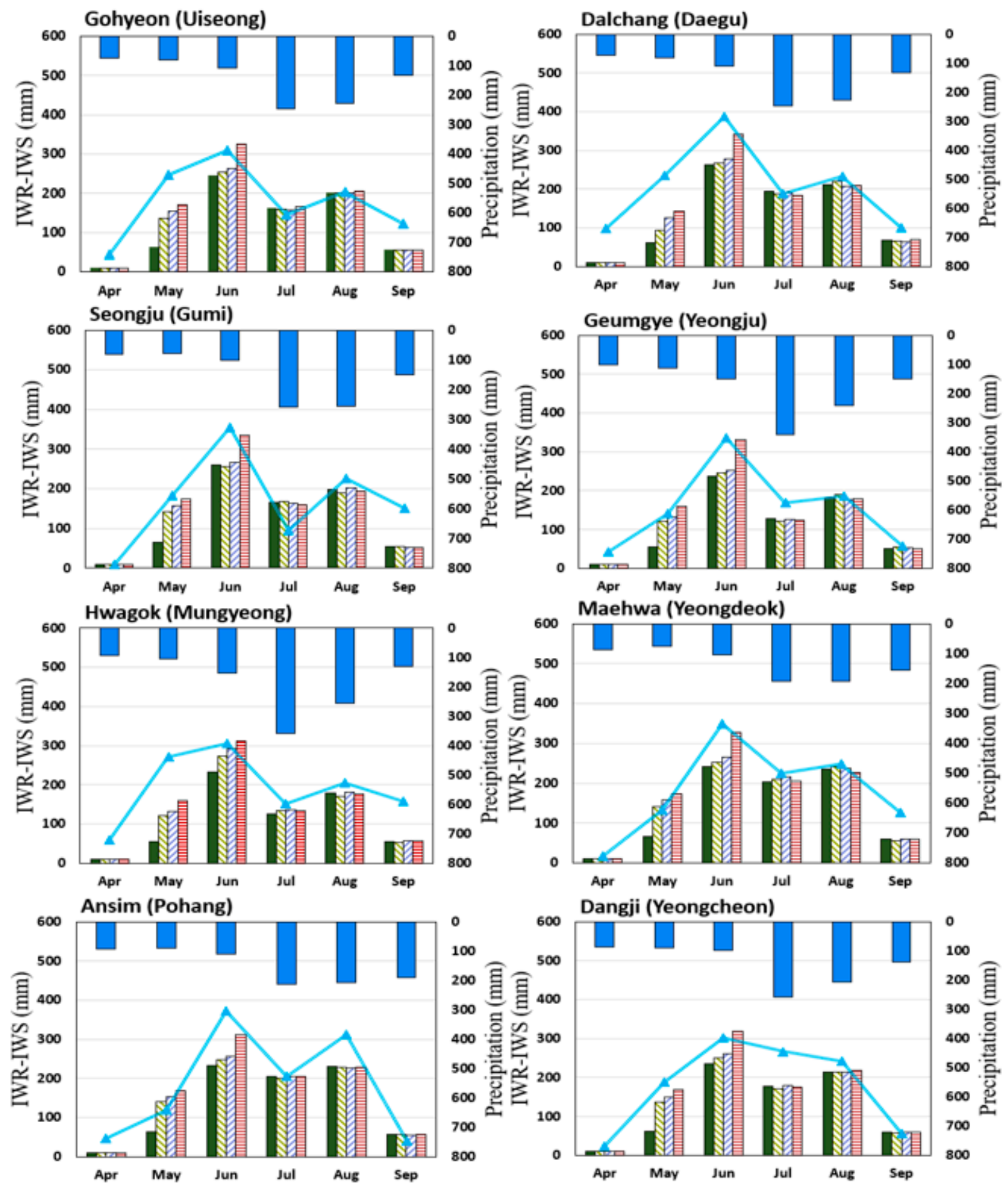

Standard $\square$ Scenario A 20 Scenario B שScenario C $\square$ Precipitation $\longrightarrow$ IWS

Figure 5. Comparisons of monthly precipitation (P), irrigation water requirement (IWR), and irrigation water supply (IWS) for transplanting scenarios. Description of the transplanting scenarios is provided in Table 2. 


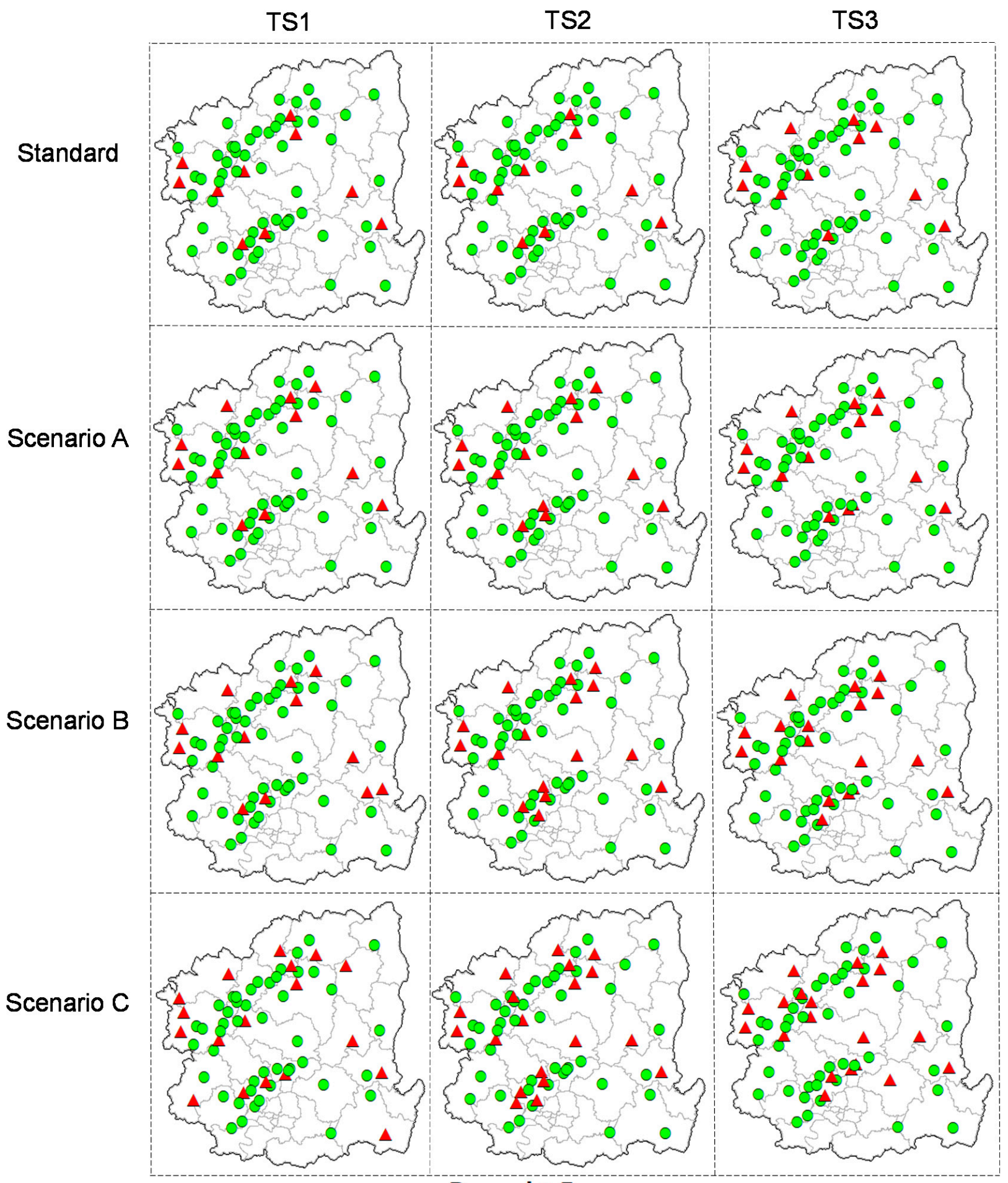

\section{Drought Frequency}

$\Delta<10$ year $\bigcirc 10$ year

Figure 6. Water supply reliability (WSR) of selected reservoirs during the TS1 (1973-1987), TS2 (1988-2002) and TS3 (2003-2017) depending on the transplanting scenarios. Description of the transplanting scenarios is provided in Table 2.

Generally, reservoirs with a watershed/irrigation area ratio of $<2.5$ and $>3.3$ were unsafe and safe respectively, and the reservoirs for which the ratio was in the range of 2.5-3.3, WSR varied depending on the transplanting scenario. The results suggested that the changed transplanting period was more influential for the WSR of agricultural reservoirs 
than climate change, especially the intensity of impact varied differently depending on the watershed/irrigation area ratio of the reservoirs.

\section{Conclusions}

Agricultural reservoirs in Korea were originally constructed to reliably supply water based on farming practices and climate-dependent rice water demands. However, rapid urbanization, socioeconomic development, extensive farm mechanization, and climate change have altered rice farming practices and water consumption patterns over time. In this article, the evolution of climate change and farming practices were assumed decisive factors in determining the water supply reliability (WSR) of 62 major agricultural reservoirs spread across the southern regions of Korea. The primary objective was to examine the reservoir storage capacities in response to the rice water demands governed by climate change and farming practices.

During the last 45 years (1973-2017), the climate of the study area became significantly warmer and wetter particularly for the rice season (April-September). The maximum water demand and supply gap occurred in June, the hottest and driest month of the rice season, while notable monsoon rainfall increments in July and August exacerbated flood threats. The climate patterns of the rice season were shifting towards intense monsoon rainfall accompanied by hotter monthly transitions at the critical stages of rice growth.

Climate warming accentuated the crop evapotranspiration $\left(\mathrm{ET}_{\mathcal{c}}\right)$ rates which were counteracted by the higher seasonal effective rainfalls resulting in stable irrigation water requirements (IWR). Apart from a notably prolonged transplanting period, the rice farming practices were almost similar to the standard farming practices prevalent at the time of reservoir construction. Climate change moderately increased the IWR, and the prolonged transplanting period was the key driver of the increase in IWR witnessed during recent years.

The WSR described the relation between the effective storage capacity of agricultural reservoirs and annual maximum water demands (AMWD) based on the paddy water balance. Climate change negligibly influenced the WSR, as most reservoirs had adequate storage capacities to accommodate AMWD during the study period. Reservoirs with large water storage capacities were able to store excess monsoon rainfall that was subsequently released during peak water demand periods. Recent changes in farming practices seriously compromised the WSR and the maximum number of unsafe reservoirs was detected for a 24-day increase in the transplanting period. It was concluded that agricultural reservoirs should have a watershed/irrigated area ratio of greater than 3.3; otherwise, these would inevitably fail to sustain reliable water supplies under the influence of climate change and/or farming practices.

\section{Limitations and Future Research}

In this study, the WSR of agricultural reservoirs was assessed based on some generalizations that need to be addressed in future investigations. Actual field conditions should be depicted by considering the extremely heterogeneous field-scale water supply losses caused by the aging water resource infrastructure. Suitable global climate models should be chosen to project the future WSR of agricultural reservoirs after analyzing the accuracy of predictions based on historic climate data. The contribution of climate and farming practices in determining the vulnerability of WSR of agricultural reservoirs should be isolated and future mitigation strategies should take into account the expected variation in climate and farming practices. Frequency of extreme climate events and their contribution to the rice yield failure risks should also be an integral part of the climate change adaptation policy. Despite the shortcomings, our findings established an upper threshold of expected water scarcity risks for developing the countermeasures against drought hazards and climate change mitigation. 
Author Contributions: Conceptualization, G.-H.C. and K.-S.C.; methodology, G.-H.C. and M.J.A.; software, G.-H.C.; validation, G.-H.C. and K.-S.C.; formal analysis, G.-H.C.; investigation, G.-H.C.; resources, K.-S.C.; data curation, G.-H.C. and K.-S.C.; writing-original draft preparation, G.-H.C. and M.J.A.; writing-review and editing, M.J.A.; visualization, G.-H.C.; supervision, K.-S.C.; project administration, K.-S.C.; funding acquisition, K.-S.C. All authors have read and agreed to the published version of the manuscript.

Funding: This work was supported by the Korea National Research Foundation (NRF) grant No. 2020R1A2C1013947 funded by the Korean government.

Conflicts of Interest: The authors declare no conflict of interest.

\section{References}

1. Nam, W.-H.; Choi, J.-Y.; Hong, E.-M. Irrigation vulnerability assessment on agricultural water supply risk for adaptive management of climate change in South Korea. Agric. Water Manag. 2015, 152, 173-187. [CrossRef]

2. Ahmad, M.J.; Cho, G.-H.; Kim, S.-H.; Lee, S.; Adelodun, B.; Choi, K.-S. Influence mechanism of climate change over crop growth and water demands for wheat-rice system of Punjab, Pakistan. J. Water Clim. Chang. 2020, 12, 1184-1202. [CrossRef]

3. Ahmad, M.J.; Choi, K.S. climatic influence on the water requirement of wheat-rice cropping system in UCC command area of Pakistan. J. Korean Soc. Agric. Eng. 2018, 60, 69-80. [CrossRef]

4. Cho, G.-H.; Ahmad, M.J.; Lee, S.; Choi, K.-S.; Nam, W.-H.; Kwon, H.-J. Influence mechanism of climate change on paddy farming practices and irrigation water demand. Paddy Water Environ. 2019, 17, 359-371. [CrossRef]

5. Ahmad, M.J.; Choi, K.-S.; Cho, G.-H.; Kim, S.-H. Future Wheat Yield Variabilities and Water Footprints Based on the Yield Sensitivity to Past Climate Conditions. Agronomy 2019, 9, 744. [CrossRef]

6. Ahmad, M.J.; Iqbal, M.A.; Choi, K.S. Climate-driven constraints in sustaining future wheat yield and water productivity. Agric. Water Manag. 2020, 231, 105991. [CrossRef]

7. Kim, D.-H.; Kim, H.; Jang, T. Evaluation of the effects of transplanting date shifts and drainage outlet raising management practices in paddy farming regions under future climates using coupled APEX-Paddy and SWAT models. Paddy Water Environ. 2021. [CrossRef]

8. Seung-Hwan, Y.; Jin-Yong, C.; Sang-Hyun, L.; Yun-Gyeong, O.; Dong Koun, Y. Climate change impacts on water storage requirements of an agricultural reservoir considering changes in land use and rice growing season in Korea. Agric. Water Manag. 2013, 117, 43-54. [CrossRef]

9. Lee, S.-H.; Shin, S.; Choi, J.-Y.; Park, J.; Yoo, S.-H. Assessing the Resilience of Agricultural Reservoirs in Ungauged Catchments under Climate Change Using a Ratio Correction Factors-Based Calibration and Run Theory. Water 2020, 12, 1618. [CrossRef]

10. Nam, W.-H.; Kim, T.; Hong, E.-M.; Choi, J.-Y. Regional Climate Change Impacts on Irrigation Vulnerable Season Shifts in Agricultural Water Availability for South Korea. Water 2017, 9, 735. [CrossRef]

11. Lee, S.-H.; Yoo, S.-H.; Choi, J.-Y.; Hwang, S. GCM-related uncertainty in forecasting irrigation and design water requirement for paddy rice fields. Int. J. Climatol. 2017, 38, 1298-1313. [CrossRef]

12. Kim, W.; Lee, J.; Kim, J.; Kim, S. Assessment of Water Supply Stability for Drought-Vulnerable Boryeong Multipurpose Dam in South Korea Using Future Dry Climate Change Scenarios. Water 2019, 11, 2403. [CrossRef]

13. Bae, H.; Ji, H.; Lim, Y.-J.; Ryu, Y.; Kim, M.-H.; Kim, B.-J. Characteristics of drought propagation in South Korea: Relationship between meteorological, agricultural, and hydrological droughts. Nat. Hazards 2019, 99, 1-16. [CrossRef]

14. Culley, S.; Noble, S.; Yates, A.; Timbs, M.; Westra, S.; Maier, H.R.; Giuliani, M.; Castelletti, A. A bottom-up approach to identifying the maximum operational adaptive capacity of water resource systems to a changing climate. Water Resour. Res. 2016, 52, 6751-6768. [CrossRef]

15. Asnaashari, A.; Gharabaghi, B.; McBean, E.; Mahboubi, A.A. Reservoir management under predictable climate variability and change. J. Water Clim. Chang. 2015, 6, 472-485. [CrossRef]

16. Masia, S.; Sušnik, J.; Marras, S.; Mereu, S.; Spano, D.; Trabucco, A. Assessment of Irrigated Agriculture Vulnerability under Climate Change in Southern Italy. Water 2018, 10, 209. [CrossRef]

17. Rocha, J.; Carvalho-Santos, C.; Diogo, P.; Beça, P.; Keizer, J.J.; Nunes, J.P. Impacts of climate change on reservoir water availability, quality and irrigation needs in a water scarce Mediterranean region (southern Portugal). Sci. Total Environ. 2020, 736, 139477. [CrossRef]

18. Hakami-Kermani, A.; Babazadeh, H.; Porhemmat, J.; Sarai-Tabrizi, M. An uncertainty assessment of reservoir system performance indices under the climate change effect. Ain. Shams. Eng. J. 2020, 11, 889-904. [CrossRef]

19. Fallah-Mehdipour, E.; Bozorg-Haddad, O.; Loáiciga, H.A. Climate-environment-water: Integrated and non-integrated approaches to reservoir operation. Environ. Monit. Assess. 2019, 192, 60. [CrossRef]

20. Haro-Monteagudo, D.; Palazón, L.; Beguería, S. Long-term sustainability of large water resource systems under climate change: A cascade modeling approach. J. Hydrol. 2020, 582, 124546. [CrossRef]

21. Green, M.; Weatherhead, E.K. The application of probabilistic climate change projections: A comparison of methods of handling uncertainty applied to UK irrigation reservoir design. J. Water Clim. Chang. 2014, 5, 652-666. [CrossRef] 
22. Verbist, K.M.J.; Maureira-Cortés, H.; Rojas, P.; Vicuña, S. A stress test for climate change impacts on water security: A CRIDA case study. Clim. Risk Manag. 2020, 28, 100222. [CrossRef]

23. Herman, J.D.; Quinn, J.D.; Steinschneider, S.; Giuliani, M.; Fletcher, S. Climate Adaptation as a Control Problem: Review and Perspectives on Dynamic Water Resources Planning Under Uncertainty. Water Resour. Res. 2020, 56, e24389. [CrossRef]

24. Mun, Y.-S.; Nam, W.-H.; Jeon, M.-G.; Bang, N.-K.; Kim, T. Assessment of Vulnerability to Drought Disaster in Agricultural Reservoirs in South Korea. Atmosphere 2020, 11, 1244. [CrossRef]

25. Song, J.-H.; Kang Moon, S.; Song, I.; Jun Sang, M. Water Balance in Irrigation Reservoirs Considering Flood Control and Irrigation Efficiency Variation. J. Irrig. Drain. Eng. 2016, 142, 04016003. [CrossRef]

26. Choi, J.-H.; Jun, C.; Liu, P.; Kim, J.-S.; Moon, Y.-I. Resolving Emerging Issues with Aging Dams under Climate Change Projections. J. Water Res. Plan. Man. 2020, 146, 04020025. [CrossRef]

27. Yoo, S.-H.; Choi, J.-Y.; Jang, M.-W. Estimation of design water requirement using FAO Penman-Monteith and optimal probability distribution function in South Korea. Agric. Water Manag. 2008, 95, 845-853. [CrossRef]

28. Yoo, S.-H.; Choi, J.-Y.; Nam, W.-H.; Hong, E. Analysis of design water requirement of paddy rice using frequency analysis affected by climate change in South Korea. Agric. Water Manag. 2012, 112, 33-42. [CrossRef]

29. Nam, W.-H.; Choi, J.-Y. Development of an irrigation vulnerability assessment model in agricultural reservoirs utilizing probability theory and reliability analysis. Agric. Water Manag. 2014, 142, 115-126. [CrossRef]

30. Lim, C.-H.; Kim, S.H.; Chun, J.A.; Kafatos, M.C.; Lee, W.-K. Assessment of Agricultural Drought Considering the Hydrological Cycle and Crop Phenology in the Korean Peninsula. Water 2019, 11, 1105. [CrossRef]

31. Hong, E.-M.; Choi, J.-Y.; Nam, W.-H.; Kim, J.-T. Decision Support System for the Real-Time Operation and Management of an Agricultural Water Supply. Irrig. Drain. 2016, 65, 197-209. [CrossRef]

32. Kim, J.; Park, J.; Jang, S.; Kim, H.; Kang, H. Improving Reservoir Operation Criteria to Stabilize Water Supplies in a Multipurpose Dam: Focused on Nakdong River Basin in Korea. Water 2018, 10, 1236. [CrossRef]

33. Yoon, P.R.; Choi, J.-Y. Effects of shift in growing season due to climate change on rice yield and crop water requirements. Paddy Water Environ. 2020, 18, 291-307. [CrossRef]

34. Doorenbos, J.; Pruitt, W.O. Crop Water Requirements: Guidelines for Predicting Crop Water Requirements; FAO Irrigation and Drainage Paper 24; FAO: Rome, Italy, 1977.

35. Yoo, S.H.; Choi, J.Y.; Jang, M.W. Estimation of Paddy Rice Crop Coefficients for FAO Penman-Monteith and Modified Penman Method. J. Korean Soc. Agric. Eng. 2006, 48, 13-23.

36. Ministry of Agriculture and Forestry (MAF). Design Criteria of Land and Water Development Plan for Agriculture (Irrigation); MAF: Souel, Korea, 1998. (In Korean)

37. Korea Rural Community Corporation (KRC). A Study on the Water Requirement Variation with the Farming Conditions in Paddy Field; KRC: Naju, Korea, 1995. (In Korean)

38. Korea Rural Community Corporation (KRC). Design Criteria of Agricultural Water Development of Water Requirement Paddy Field; KRC: Naju, Korea, 1980. (In Korean)

39. Korea Rural Community Corporation (KRC). Improvement of Estimation Methodology for Paddy Rice Water Demand; KRC: Naju, Korea, 2020. (In Korean)

40. Jo, Y.-J.; Song, J.-H.; Her, Y.; Provolo, G.; Beom, J.; Jeung, M.; Kim, Y.-J.; Yoo, S.-H.; Yoon, K.-S. Assessing the Potential of Agricultural Reservoirs as the Source of Environmental Flow. Water 2021, 13, 508. [CrossRef]

41. Islam, A.R.M.T.; Shen, S.; Yang, S.; Hu, Z.; Chu, R. Assessing recent impacts of climate change on design water requirement of Boro rice season in Bangladesh. Theor. Appl. Climatol. 2019, 138, 97-113. [CrossRef]

42. Sen, P.K. Estimates of the Regression Coefficient Based on Kendall's Tau. J. Am. Stat. Assoc. 1968, 63, 1379-1389. [CrossRef]

43. Ahmad, M.J.; Choi, K.S. Influence of climate variables on FAO Penman-Monteith reference evapotranspiration in the Upper Chenab Canal command area of Pakistan. Paddy Water Environ. 2018, 16, 425-438. [CrossRef] 